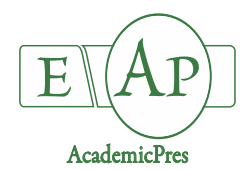

Blanda G et al. $(2020)$
Notulae Botanicae Horti Agrobotanici Cluj-Napoca 48(4):2306-2315
DOI:10.15835/48412108
Research Article

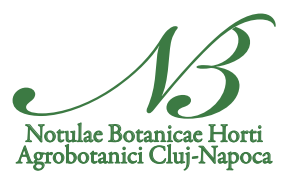

\title{
Phenolic profile and physicochemical characterization of quince (Cydonia oblonga Mill) fruits at different maturity index
}

\author{
Giampaolo BLANDA ${ }^{1}$, Maria J. RODRIGUEZ-ROQUE², \\ Patrizia COMANDINI ${ }^{1}$, Maria A. FLORES-CORDOVA ${ }^{2}$, \\ Nora A. SALAS-SALAZAR ${ }^{2}$, Oscar CRUZ-ALVAREZ², \\ Mayra C. SOTO-CABALLERO ${ }^{2 *}$ \\ ${ }^{1}$ Universita di Bologna, Dipartimento di Scienze degli Alimenti, Piazza Goidanich, 60, Cesena, FC, 47521, \\ Italy;g.blanda@pizzoli.it; patricom83@yahoo.it \\ ${ }^{2}$ Universidad Autonoma de Chihuahua, Facultad de Ciencias Agrotecnologicas, Presa de la Amistad 2015, Barrio la Presa, \\ Cuauhtemoc,Chihuahua,31510,Mexico;mjrodriguez@uach.mx; mafloresc@uach.mx;nsalas@uach.mx; ocruz@uach.mx; \\ masotoc@uach.mx ("corresponding author)
}

\begin{abstract}
The ripening of fruits is a determinant factor on the composition of phytochemical compounds such as phenolic compounds. In this study the phenolic profile of quince fruits was determined as a function of its maturity index. Based on the total soluble solids (TSS) and the acidity (TA) of the fruits, four maturity indexes were established $(12.55,14.56,21.86$ and 24.77), using the ratio of TSS/TA. The phenolic profile of quince fruits with different maturity indexes were obtained by a reversed-phase HPLC-DAD and HPLC-DAD/MS. A PCA loading plot was generated to explain the relationship between physicochemical parameters and the phenolic compounds. The phenolic compounds identified in the quince fruits were 3-O-caffeoylquinic acid, catechin, 4-O-caffeoylquinic acid, 5-O-caffeoylquinic acid, coumaric acid, quercetin-3-O-rutinoside and quercetin-3- $O$-glycosides. The maturity index increase caused in general a reduction of phenolic compounds, these compounds were also influenced by $\mathrm{pH}$ and acidity of fruits. Quince is a valuable source of natural phenolic antioxidants, and can be used as raw material to elaborate diverse food products, providing important functional properties.
\end{abstract}

Keywords: phenolic compounds; physicochemical parameters; quince; ripening

\section{Introduction}

Quince (Cydonia oblonga Miller) is a climacteric pome fruit that belongs to the Rosaceae family (Benzarti et al., 2015; Hussain et al., 2019). It is a round or pear-shaped fruit with yellow skin and a sour and bitter taste but at the same time is really aromatic (Rasheed et al., 2018). Quince fruits have an important nutritional content as they are a rich source of organic acids, sugars, fibres and minerals. Additionally, they also contain compounds with functional and antioxidant features, being the phenolic compounds the most 
important. Consumption of quince fruit have been related with health due to their hypoglycaemic action, antiinflammatory, antimicrobial and anticancer activities (Leonel et al., 2016; Rasheed et al., 2018).

It is well known that the sensory, physicochemical and nutritional properties of quince fruits depend on several factors such as species, variety, crop, region, climatic conditions and maturity (Rios de Souza et al., 2014). The latest factor is determinant on the quality of fruit since, the ripening involves a series of physiological and biochemical events leading to changes in colour, flavour, aroma and texture (Singal et al., 2012), but also on the nutritional content and taste of products. A reliable measure of fruit quality is the maturity index, which relates sourness and sugar level (Kvikliene et al., 2006). Many biochemical reactions related with flavour and taste properties during ripening are attributed to the phenolic compounds present in the fruits (Rios de Souza et al., 2014). Phenolic compounds are secondary metabolites widely found in fruits, mostly represented by flavonoids and phenolic acids (Pasqualone et al., 2014). These compounds are important participants also on antioxidants properties of quince fruits (Gharras, 2009; Cheynier, 2012).

The determination of phenolic compounds in quince has increasing interest in recent years. Some studies have evaluated the phenolic profile in the pulp and peel of quince (Silva et al., 2002; Silvia et al., 2004; Stojanović et al., 2017), as well as on quince-based products (Silvia et al., 2000; Ferreira et al., 2004). More recently, Baroni et al. (2018) evaluated the content of phenolic compounds and their relationship with the antioxidant capacity of quince fruit before and after jam processing. Maghsoudlou et al. (2019) studied the effect of heating on the phenolic content and antioxidant capacity of quince fruit. However, there is a lack of information on the relationship of these compounds with the ripening of quince fruits. The objective of study was to determine the phenolic profile and physicochemical parameters of quince fruits as a function of maturity index.

\section{Materials and Methods}

\section{Raw material and preparation}

Quince fruits (Cydonia oblonga Mill) cultivar 'Gigante di Wranja' obtained from local supermarket from Italy were used for this study. Fruits were kept under refrigeration conditions $\left(4^{\circ} \mathrm{C}\right)$ until analysis (less than 1 week). The samples were washed and cut into pieces, removing cores and seeds. The quince puree was obtained using a Microtron MB 550 Laboratory mixer (Kinematica, Russia) and was obtained by mixing the quince pulp and peel.

\section{Physicochemical determinations}

Measurement of total soluble solids (TSS) and $\mathrm{pH}$ were carried out at $25^{\circ} \mathrm{C}$ using a SMART-1 Digital Benchtop refractometer (Atago, USA) and a HI $5521 \mathrm{pH}$ meter (Hanna, Instruments, USA), respectively. Titratable acidity (TA) was measured through the titration of fruit juice with $0.1 \mathrm{~N} \mathrm{NaOH}$, until achieving the neutralization by phenolphthalein indicator (Mkhathini et al., 2017). The results were expressed as a percentage of citric acid equivalents Maturity index was calculated as the TSS/TA ratio (Navarro Acosta et al., 2010; Mkhathini et al., 2017). Dry matter was determined according to the method described by BehboudiJobbehdar et al. (2013) in a convection oven (SMO1E, Shel-Lab, USA) at $105^{\circ} \mathrm{C}$ during 24 hours until a constant mass was reached. All physicochemical parameters were analysed in triplicate.

\section{Phenolic compounds extraction}

Extraction of phenols compounds was performed following the methodology reported by Silva et al. (2002) with some modifications. Briefly, a portion $(30 \mathrm{~g})$ of quince puree was added in an aqueous solution containing $0.3 \mathrm{M}$ of $\mathrm{NaCl}$ and ascorbic acid $(0.5 \%)$ (ratio 1:1,w/w) and homogenized with an Ultra Turrax (IKA-Werke mod. T 25 basic, Staufen, Germany) at $17500 \mathrm{rpm}$ for $1 \mathrm{~min}$. The blend was let to stand for 2 hours and then $10 \mathrm{~g}$ of sample was taken and mixed with $10 \mathrm{~mL}$ of the solution of $\mathrm{NaCl}$ and ascorbic acid, the 
blend was homogenized at $11,000 \mathrm{rpm}$ for $1 \mathrm{~min}$, and centrifuged at $24,000 \mathrm{rpm}$ at $10{ }^{\circ} \mathrm{C}$ for $10 \mathrm{~min}$. The supernatant liquid was recovered and placed on an SPE C18 column previously activated with $5 \mathrm{~mL}$ of methanol, $5 \mathrm{~mL}$ of distilled water and $5 \mathrm{~mL}$ of solution formic acid solution (3.0\%). The retained phenolic fraction was then eluted with methanol $(2 \mathrm{~mL})$, filtered and placed in the freezer at $-47^{\circ} \mathrm{C}$. The determination was made in triplicate.

\section{HPLC analysis and phenolic compounds determination}

The polyphenolic extracts were analysed in the 1100 series HPLC equipped with a binary pump, a degasser, automatic sampler, UV-vis Diode array detector and a mass spectrometer detector (Agilent Technologies, Palo Alto, CA). A Gemini 3M C18 column (100 x 2 mm x 3 mm, Phenomenex, Torrance, CA) was used. The mobile phase was: acidified water $(2.5 \% \mathrm{v} / \mathrm{v}$ formic acid) (solvent A) and acid methanol $(2.5 \%$ $\mathrm{v} / \mathrm{v}$ formic acid) (solvent B). The HPLC system was conditioned with the mobile phase at least for an hour or until a stable baseline was obtained. The following linear elution gradient was employed: at $0 \mathrm{~min} 95 \%$ solvent $\mathrm{A}$, at $10 \mathrm{~min} 88 \% \mathrm{~A}$ was reached and held constant (81\%) from 25 and $35 \mathrm{~min}$, at $40 \mathrm{~min}$ the solvent $\mathrm{A}$ decreased to $76 \%$ and finally at $56 \mathrm{~min} 30 \%$ solvent A was reached. Total execution time was $70 \mathrm{~min}$. An injection volume of $5 \mu \mathrm{l}$ and a flow rate of $0.25 \mathrm{~mL} / \mathrm{min}$ were used (Comandini et al., 2008; Blanda et al., 2009). Chromatograms were recorded at 280, 320 and $350 \mathrm{~nm}$.

The different phenolic compounds were identified by their UV spectra recorded with the diode array detector, chromatographic comparisons (retention times) and fragmentation of molecular ions. Phenolic quantification was achieved by the absorbance recorded in the chromatograms and was expressed as a relative area percent.

\section{Statistical analysis}

The one-way analysis of variance (ANOVA) and the Tukey-test were used to determine statistically significant differences between the variables studied. A multivariate analysis was also applied using PCA and the geometric representation for the main factors plotted. Statistical analysis was carried out using Minitab 16 software (Statistical Software, USA).

\section{Results}

\section{Physicochemical properties of quince fruits}

The quince samples were classified in four groups basing on their maturity index (MI). The MI values obtained were $12.55 \pm 0.62,14.56 \pm 0.37,21.86 \pm 0.59$ and $24.77 \pm 0.51$. Figure 1 shows the physicochemical properties of quince fruits at different maturity index.

An inverse relationship between titratable acidity and maturity index was observed, resulting in a TA reduction from 1.44 to $0.58 \%$ when $\mathrm{MI}$ increased; while that the $\mathrm{pH}$ values raised when the maturity index of fruit increased (Figure 1). Total soluble solids (TSS) and dry matter (DM) of quince fruits varied from 13.96 to $18.14^{\circ} \mathrm{Bx}$ and from 16.84 to $22.5 \%$, respectively by effect of MI (Figure 1 ).

The equations obtained can be used to estimate the physicochemical parameters of quince fruits as a function of maturity index. The correlation coefficient values $\left(\mathrm{R}^{2}\right)$ were equal or greater than 0.91 , indicating an adequate adjustment of the experimental data. 

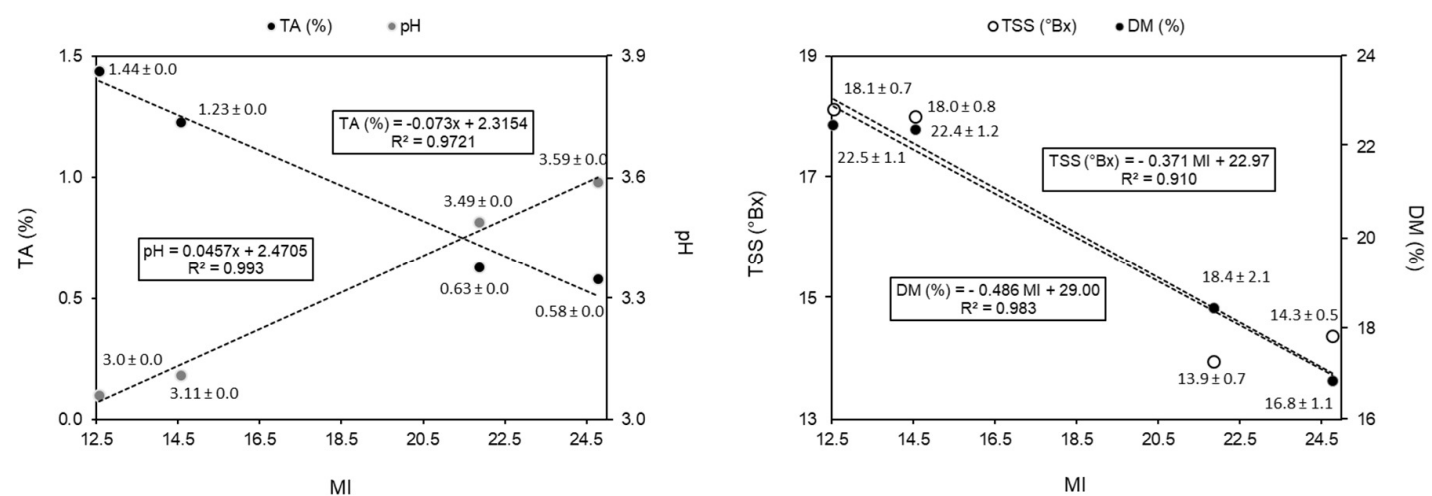

Figure 1. Correlation between physicochemical characteristics of quince fruit and its maturity index (MI).

TA-titratable acidity; TSS- total soluble solids; DM-dry matter

\section{Phenolic profile of quince fruits}

The phenolic profile of quince fruits was obtained by HPLC (Figure 2). Phenolic compounds were identified on the basis their UV-VIS spectra, retention times and fragmentation of molecular ions according to data from the literature (Table 1).

The chromatogram presented in Figure 2 shows the peaks of the 8 compounds identified. The caffeoylquinic acids: 3 - $O$-caffeoylquinic acid its isomers $4-O$-caffeoylquinic acid and 5-O-caffeoylquinic acid were found in the quince fruits analysed (Figure 2). Absorbance ( $325 \mathrm{~nm}: 290$ sh:245 nm), retention times from 14.36 to 27.37 and fragmentation of ions characteristic $\mathrm{m} / \mathrm{z}$ of these caffeoylquinic acids, allowed their identification based on literature data (Table 1) (Plazonić et al., 2014; Chen et al., 2014; Baroni et al., 2018). 5-O-caffeoylquinic acid was the predominant compound in the quince (largest peak). Quince fruits were also source of p-coumaric acid, which is a hydroxycinnamic acid derivative (Figure 2 and Table 1).

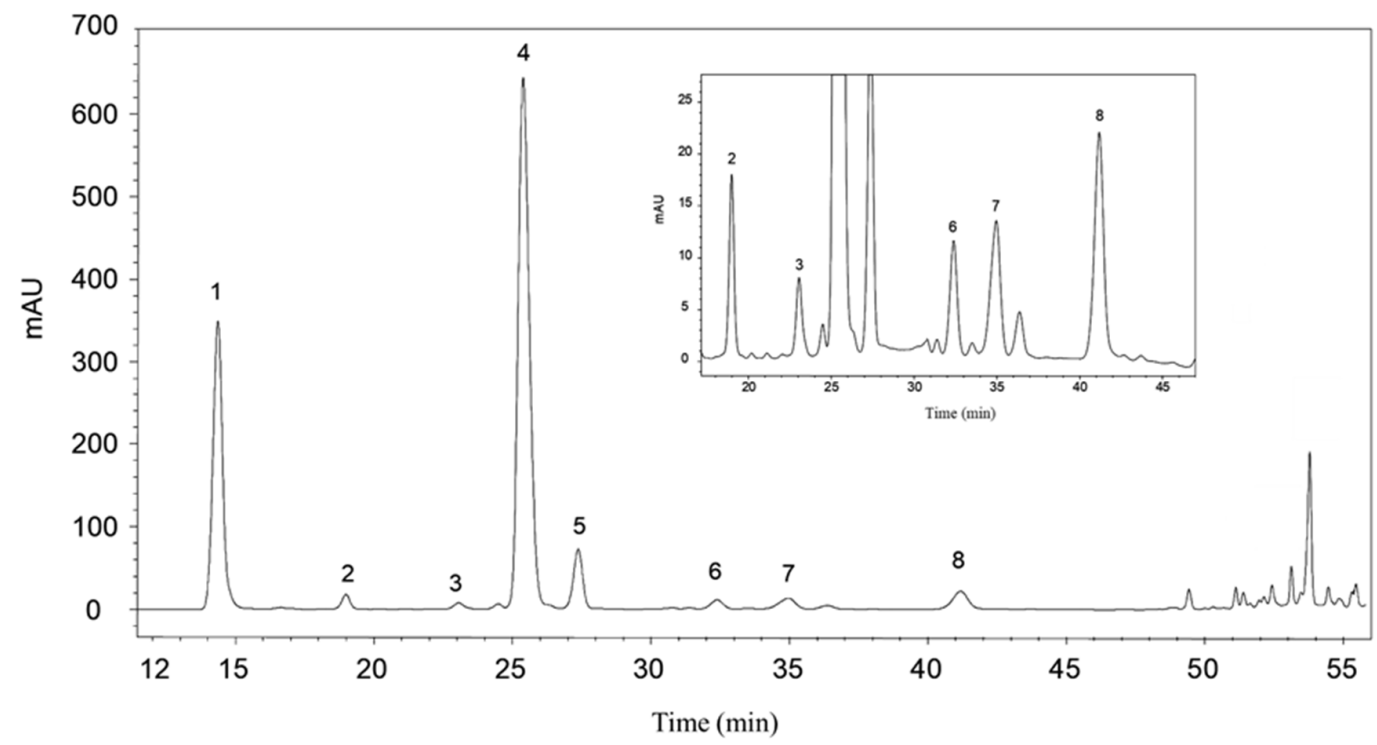

Figure 2. HPLC phenolic profile of quince fruits. Detection at $350 \mathrm{~nm}$. Peaks: (1) 3-O-caffeoylquinic acid, (2) catechin, (3) 4- $O$-caffeoylquinic acid, (4) 5- $O$-caffeoylquinic acid, (5) 3,5-dicaffeoylquinic acid, (6) coumaric acid, (7) quercetin-3-O-rutinoside and (8) quercetin-3-O-glycosides 
Table 1. Identification of compounds found in quince fruits, according to their retention time, maximum

\begin{tabular}{|c|c|c|c|c|}
\hline Peak & Compound & RT $(\min )$ & $\lambda_{\max }(\mathrm{nm})$ & Characteristic ions $(\mathrm{m} / \mathrm{z})$ \\
\hline 1 & 3-0-caffeoylquinic acid & 14.36 & $325 ; 290 ; 245$ & $353 ; 354$ \\
\hline 2 & Catechin & 18.98 & $310 ; 240$ & - \\
\hline 3 & 4-0-caffeoylquinic acid & 23.06 & $325 ; 285 ; 242$ & $181 ; 223 ; 399 ; 471 ; 580$ \\
\hline 4 & 5-0-dicaffeoylquinic acid & 25.38 & $325 ; 295 ; 245$ & $191 ; 353 ; 354$ \\
\hline 5 & 3,5-dicaffeoylquinic acid & 27.37 & $325 ; 295 ; 245$ & $289 ; 431 ; 432$ \\
\hline 6 & p-Coumaric acid & 32.38 & $305 ; 240$ & $433 ; 547 ; 593$ \\
\hline 7 & Quercetin-3-0-rutinoside & 34.96 & $315 ; 240$ & $289 ; 461$ \\
\hline 8 & Quercetin-3-0-glycosides & 41.17 & $330 ; 295 ; 245$ & $180 ; 435 ; 345 ; 391$ \\
\hline
\end{tabular}

absorbance and negative ionisation mass spectra

$\mathrm{RT}$, retention time; MS2 $(\mathrm{m} / \mathrm{z})$, daughter ions produced from $[\mathrm{M}-\mathrm{H}]-$ fragmentation; $\lambda$ max, maximum absorbance for compound identification by UV-VIS spectra

\section{Phenolic composition of quince fruits}

Figure 3 shows the phenolic composition of quince fruits at different maturity index. Statistically significant differences $(p<0.05)$ were obtained in the composition of phenolic compounds of fruits with different maturity index (Figure 3 ). The concentration of the 3- $O$-caffeoylquinic and 5-O-caffeoylquinic acids in the quince fruits varied from 2.93 to 4.20 and from 4.84 to $8.81 \mathrm{mg} / 100 \mathrm{~g}$ fruit, respectively. In general, the phenolic composition decreased by the rise of fruits MI, obtaining a decrease up 39\% and $45 \%$ on 3-Ocaffeoylquinic and 5-O-caffeoylquinic acids, respectively (Figure 3).

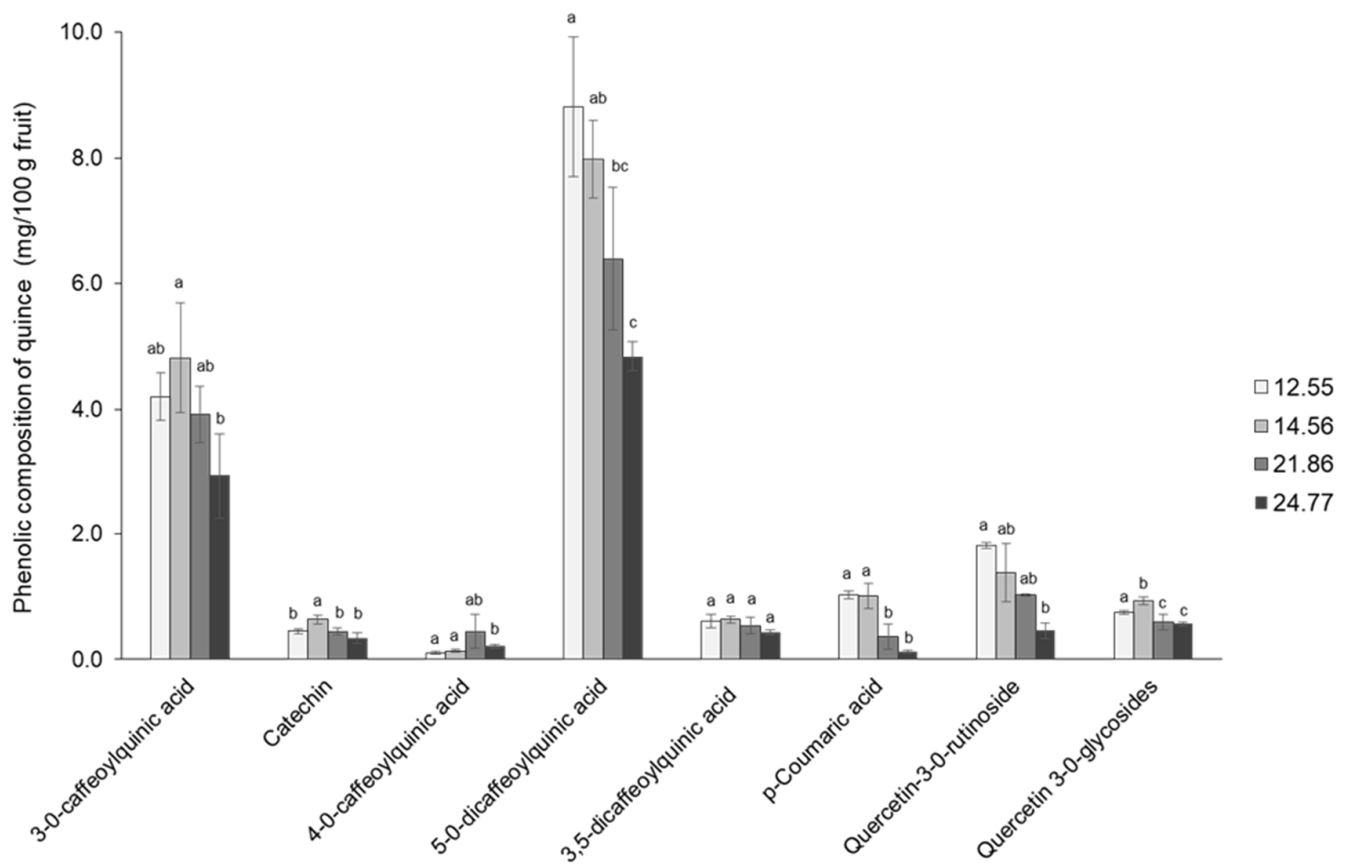

Figure 3. Phenolic Composition of quince fruits with different maturity index (values obtained at $320 \mathrm{~nm}$ )

\section{Correlation between phenolic compounds and physicochemical properties of quince fruits}

The relationship between physiochemical characteristics and phenolic compounds of quince fruits is shown in the loading plot (Figure 4). To explain the graph, it is important to know that when two vectors are close, forming a small angle, the two variables they represent are positively correlated (Eriksson et al., 2013). The ripeness degree inversely affected the phenolic content of quince fruits, therefore, when the MI increased, 
a reduction of phenolic compounds was obtained (Figure 4). Likewise, a direct relationship between the $\mathrm{pH}$ and the maturity stage of the quince's fruits can be observed.

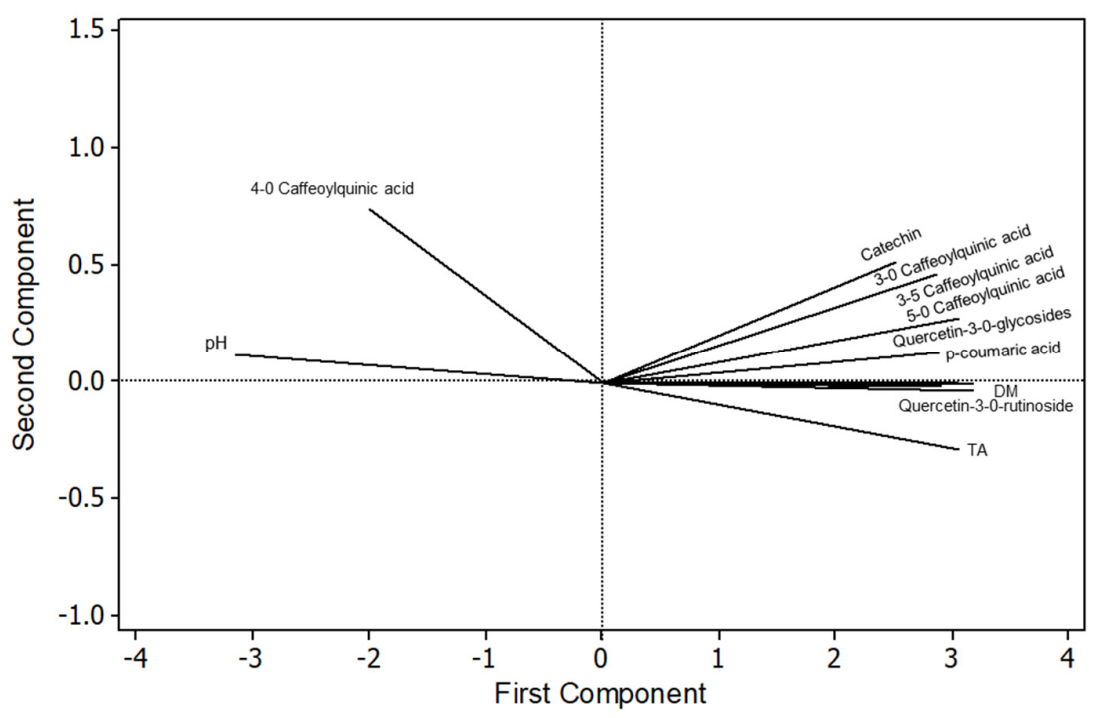

Figure 4. Principal component analysis (PCA) loading plot of physicochemical characteristics and phenolic compounds of quince fruits

\section{Discussion}

\section{Physicochemical properties of quince fruits}

The acidity of quince fruits decreases when the MI increased. This parameter is generally attributed to proton release from organic acids, which are metabolized in the respiration process as that fruit ripens (Akhtar and Rab, 2015; Famiani et al., 2015). Rasheed et al. (2018) studied also quince and reported a similar trend in the acidity of fruits.

Contrarily to data reported for other fruits, the total soluble solids (TSS) decreased as that MI increased, this result was verified with the starch-iodine test, being consistent. This can be due to quince composition, which includes high content of pectin (1.83\%) (Acikgoz, 2011; Borazan and Acikgoz, 2017). TSS assessment by refractometry applied include sugars but also acids and small amounts of dissolved vitamins, proteins, pigments, phenolics, and minerals (Magwaza and Opara, 2015). The trend obtained for TSS is also supported by the reduction in dry matter obtained (Figure 1).

\section{Phenolic profile of quince fruits}

The phenolic profile obtained to quince fruits is similar to reported in previous studies (Silva et al., 2000; Silva et al., 2004; Baroni et al., 2018).

As well as in other fruits like apples and pears (Zampelas and Micha, 2015), the 5-O-caffeoylquinic acid was the major the phenolic acid of the quince fruits. This phenolic compound is the main substrate of polyphenol oxidase enzyme, which explains the susceptibility of these fruits to enzymatic browning (Sunil, 2016). The range obtained of $5-O$-caffeoylquinic acid $(4.84-8.81 \mathrm{mg} / \mathrm{g})$ is higher than reported for pulp and peel of pear (0.08-0.66 and 0.32-3.33 mg/g, respectively) (Brahem et al., 2017) and less than range reported in other studies for quince fruits (10.7 to $15.7 \mathrm{mg} / \mathrm{g}$ ) (Carvalho et al., 2010; Costa et al., 2009). This last can be 
attributed to factors, such as variety, cultivar, soil and climate related factors, fertilization and others (Klepacka et al., 2011).

Caffeic acid has been found to be the most effective agent to diseases resistance response found in many fleshy fruits during ripening (Singh et al., 2010). The biosynthesis of caffeic acids involves in a broad range of stress responses, due to mechanisms underlying their biosynthesis and protective action. Like other phenolics, they are accumulated inside vacuoles or in the apoplast during leaf ageing, and their biosynthesis apparently occur within chloroplasts since the last enzyme that catalysis their biosynthesis is described as chloroplastic (Mondolot et al., 2006). The monomeric flavonols as the quercetin-3-O-rutinoside and quercetin-3-0glycosides were also detected in the quince in a range to $0.46-1.81$ and $0.57-0.93 \mathrm{mg} / \mathrm{g}$, respectively. These values are much higher than those reported for pears fruits (Brahem et al., 2017). Both compounds are considered potent antioxidants due to their ability to scavenge the free radicals (Gharras, 2009). Additionally, it has been reported that they also contribute to the quality characteristics of fruits including astringency, texture, taste and colour (Arena et al., 2012).

\section{Relationship between phenolic profile and physicochemical properties of quince fruits}

The reduction of phenolic compounds during the maturation of fruits explains the decline astringency and bitterness in fruits (Butkhup and Samappito, 2011). A decline in the phenolic acids content during ripening was also reported in fruits such as blackberries, strawberries (Häkkinen et al., 2000), white grapes, mango, banana (Wang and Lin, 2000) and tomato (Gougoulias et al., 2018) and apple (Silva et al., 2019). This pattern suggests the degradation of phenolic compounds and their utilization in the biosynthesis of other compounds and/or association with other cellular compounds by stable covalent links (Arena et al., 2012).

\section{Conclusions}

In this study determined the phenolic profile and physicochemical parameters of quince fruits as a function of maturity index. Eight phenolic compounds were identified in quince fruits, being the major the 3$O$-caffeoylquinic and 5-O-caffeoylquinic acids. Significant differences on phenolic composition by effect of maturity index were obtained. The phenolic compounds were correlated with the maturity index and the physicochemical factors of the quince fruits, obtaining in general, an inverse relation between the phenolic compounds and maturity index. The quince fruits are an important source of phenolic compounds especially when they have a low maturity index.

\section{Authors' Contributions}

GB (Methodology); PC (Methodology); MJR-R (Methodology, Review and Editing); MAF-C (Methodology, Review and Editing); NAS-S (Methodology, Review and Editing); OC-A (Review and Editing); MCS-C (Methodology, Supervision and Writing)

All authors read and approved the final manuscript.

\section{Acknowledgements}

Research support was provided by the Universita di Bologna, Dipartimento di Scienze degli Alimenti, Cesena. 


\section{Conflict of Interests}

The authors declare that there are no conflicts of interest related to this article.

\section{References}

Acikgoz C (2011). Extraction and characterization of pectin obtained from Quince fruits (Cydonia vulgaris pers) grown in Turkey. Asian Journal of Chemistry 23:149-152.

Akhtar I, Rab A (2015). Effect of fruit ripening stages on strawberry (Fragaria $x$ ananassa. Duch) fruit quality for fresh consumption. Journal of Agricultural Research 53(3):43-424.

Arena ME, Postemsky, P, Curvetto, NR (2012). Accumulation patterns of phenolic compounds during fruit growth and ripening of Berberis buxifolia, a native Patagonian species. New Zealand Journal of Botany 50(1):15-28. https://doi.org/10.1080/0028825X.2011.638644

Baroni MV, Gastaminza J, Podio NS, Lingua MS, Wunderlin DA, Rovasio JL, ... Ribotta PD (2018). Changes in the antioxidant properties of quince fruit (Cydonia oblonga Miller) during jam production at industrial scale. Journal of Food Quality 2018:1-9. https://doi.org/10.1155/2018/1460758

Behboudi-Jobbehdar S, Soukoulis C, Yonekura L, Fisk I (2013). Optimization of spray-drying process conditions for the production of maximally viable microencapsulated $L$. acidophilus NCIMB 701748. Drying Technology 31(11):1274-1283. https://doi.org/10.1080/07373937.2013.788509

Benzarti S, Hamdi H, Lahmayer I, Toumi W, Kerkeni A, Belkadhi K, Sebei, H (2015). Total phenolic compounds and antioxidant potential of quince (Cydonia oblonga Miller) leaf methanol extract. International Journal of Innovation and Applied Studies 13(3):518-526.

Blanda G, Cerretani L, Cardinali A, Barbieri S, Bendini A, Lercker G (2009). Osmotic dehydro freezing of strawberries: Polyphenolic content, volatile profile and consumer acceptance. LWT-Food Science and Technology 42(1):3036. https://doi.org/10.1016/j.lwt.2008.07.002

Borazan AA, Acikgoz C (2017). Effect of quince variety on the quality of pectin: Chemical composition and characterization. International Journal of Pharmaceutical, Chemical \& Biological Sciences 7(4):393-400. https://hdl.handle.net/11552/1373

Butkhup L, Samappito S (2011). Changes in physico-chemical properties, polyphenol compounds and antiradical activity during development and ripening of maoluang (Antidesma bunius L. Spreng) fruits. Journal of Fruit and Ornamental Plant Research 19(1):85-99.

Brahem M, Renard CM, Eder S, Loonis M, Ouni R, Mars M, Le Bourvellec C (2017). Characterization and quantification of fruit phenolic compounds of European and Tunisian pear cultivars. Food Research International 95:125-133. https://doi.org/10.1016/j.foodres.2017.03.002

Carvalho M, Silva BM, Silva R, Valentão P, Andrade PB, Bastos ML (2010). First report on Cydonia oblonga Miller anticancer potential: Differential antiproliferative effect against human kidney and colon cancer cells. Journal of Agricultural and Food Chemistry 58:3366-3370. https://doi.org/10.1021/jf903836k

Chen F, Long X, Liu Z, Shao H, Liu L (2014). Analysis of phenolic acids of Jerusalem artichoke (Helianthus tuberosus L.) responding to salt-stress by liquid chromatography/tandem mass spectrometry. Science World Journal 2014:1-8. https://doi.org/10.1155/2014/568043

Cheynier V (2012). Phenolic compounds: From plants to foods. Phytochemistry Reviews 11(2-3):153-177. https://doi.org/10.1007/s11101-012-9242-8

Comandini P, Blanda G, Cardinali A, Cerretani L, Bendini A, Caboni MF (2008). CZE separation of strawberry anthocyanins with acidic buffer and comparison with HPLC. Journal of Separation Science 31(18):3257-3264. https://doi.org/10.1002/jssc.200800199

Costa RM, Magalhães AS, Pereira JA, Andrade PB, Valentão P, Carvalho M, Silva BM (2009). Evaluation of free radicalscavenging and antihemolytic activities of quince (Cydonia oblonga) leaf: A comparative study with green tea (Camellia sinensis). Food and Chemical Toxicology 47:860-865. https://doi.org/10.1016/j.fct.2009.01.019

Eriksson L, Byrne T, Johansson E, Trygg J, Vikström C (2013). Multi-and megavariate data analysis basic principles and applications. 3rd ed. Sweden: Umetrics Academy pp 33-35. 
Famiani F, Battistelli A, Moscatello S, Cruz-Castillo JG, Walker RP (2015). The organic acids that are accumulated in the flesh of fruits: Occurrence, metabolism and factors affecting their contents-a review. Revista Chapingo Serie Horticultura 21(2):97-128. https://doi.org/10.5154/r.rchsh.2015.01.004

Ferreira IM, Pestana N, Alves MR, Mota FJ, Reu C, Cunha S, Oliveira MBP (2004). Quince jam quality: microbiological, physicochemical and sensory evaluation. Food Control 15(4):291-295. https://doi.org/10.1016/S09567135(03)00079-3

Gharras H (2009). Polyphenols: Food sources, properties and applications - a review. International Journal of Food Science \& Technology 44(12):2512-2518. https://doi.org/10.1111/j.1365-2621.2009.02077.x

Gougoulias N, Papachatzis A, Vyrlas P, Kalfountzos D, Karaboula A (2018). Evaluation of certain qualitative and quantitative characteristics of hydroponic tomato grown to a geothermal and a conventional greenhouse. Annals of the University of Craiova 23:115-120.

Häkkinen K, Alen M, Kallinen M, Newton RU, Kraemer WJ (2000). Neuromuscular adaptation during prolonged strength training, detraining and re-strength-training in middle-aged and elderly people. European Journal of Applied Physiology 83(1):51-62. https://doi.org/10.1007/s004210000248

Hussain PR, Rather SA, Suradkar PP, Ayob O (2019). Gamma irradiation treatment of quince fruit (Cydonia oblonga Mill): Effect on post-harvest retention of storage quality and inhibition of fungal decay. Journal of Radiation Research and Applied Sciences 12(1):118-131. https://doi.org/10.1080/16878507.2019.1618588

Klepacka J, Gujska E, Michalak J (2011). Phenolic compounds as cultivar-and variety-distinguishing factors in some plant products. Plant Foods for Human Nutrition 66(1):64-69. https://doi.org/10.1007/s11130-010-0205-1

Kvikliene N, Kviklys D, Viskelis P (2006). Changes in fruit quality during ripening and storage in the apple cultivar Auksis'. Journal of Fruit and Ornamental Plant Research 14:195-202.

Leonel M, Leonel S, Tecchio MA, Mischan MM, Moura MF, Xavier D (2016). Characteristics of quince fruits cultivars (Cydonia oblonga Mill.) grown in Brazil. Australian Journal of Crop Science 10(5):711-716. https://doi.org/10.21475/ajcs.2016.10.05.p7425

Maghsoudlou Y, Ghajari MA, Tavasoli S (2019). Effects of heat treatment on the phenolic compounds and antioxidant capacity of quince fruit and its tisane's sensory properties. Journal of Food Science and Technology 56(5):23652372. https://doi.org/10.1007/s13197-019-03644-6

Magwaza LS, Opara UL (2015). Analytical methods for determination of sugars and sweetness of horticultural products - A review. Scientia Horticulturae 184:179-192. https://doi.org/10.1016/j.scienta.2015.01.001

McClure KA, Gong Y, Song J, Vinqvist-Tymchuk M, Campbell Palmer L, Fan L, ... Myles S (2019). Genome-wide association studies in apple reveal loci of large effect controlling apple polyphenols. Horticulture Research 6(107):1-12. https://doi.org/10.1038/s41438-019-0190-y

Mkhathini KM, Magwaza LS, Workneh TS, Mwithiga G (2017). Determinations of physical and chemical properties of kwazulu-natal's household white peach 'landrace' in relation to extension services-a case study of impendle local municipality. South African Journal of Agricultural Extension 45(2):95-109. http://dx.doi.org/10.17159/2413-3221/2017/v45n1a439

Mondolot L, La Fisca P, Buatois B, Talansier E, De Kochko A, Campa C (2006). Evolution in caffeoylquinic acid content and histolocalization during Coffea canephora leaf development. Annals of Botany 98(1):33-40. http://dx.doi.10.1093/aob/mcl080

Navarro A, Josefa M, Gómez Gómez A, Pérez Pérez JG, Botía P (2010). Effect of saline conditions on the maduration process of Clementine Clemenules fruits on two different rootstocks. Spanish Journal of Agricultural Research 8(sp iss2):s21-s29. http://hdl.handle.net/20.500.11914/2244

Pasqualone A, Delvecchio LN, Mangini G, Taranto F, Blanco A (2014). Variability of total soluble phenolic compounds and antioxidant activity in a collection of tetraploid wheat. Agricultural and Food Science 23(4):307-316. https://doi.org/10.23986/afsci.47985

Plazonić A, Bucar F, Maleš Ž, Mornar A, Nigović B, Kujundžić N (2009). Identification and quantification of flavonoids and phenolic acids in burr parsley (Caucalis platycarpos L.), using high-performance liquid chromatography with diode array detection and electrospray ionization mass spectrometry. Molecules 14(7):2466-2490. https://doi.org/10.3390/molecules 14072466

Rasheed M, Hussain I, Rafiq S, Hayat I, Qayyum A, Ishaq S, Awan MS (2018). Chemical composition and antioxidant activity of quince fruit pulp collected from different locations. International Journal of Food Properties 21(1):2320-2327. https://doi.org/10.1080/10942912.2018.1514631 
Rios de Souza V, Aparecida Pimenta Pereira P, Carla Marques Pinheiro A, Carlos de Oliveira Lima L, Pio R, Queiroz F (2014). Analysis of the subtropical blackberry cultivar potential in jelly processing. Journal of Food Science 79(9):S1776-S1781. https://doi.org/10.1111/1750-3841.12565

Silva BM, Andrade PB, Ferreres F, Domingues AL, Seabra RM, Ferreira MA (2002). Phenolic profile of quince fruit (Cydonia oblonga Miller) (pulp and peel). Journal of Agricultural and Food Chemistry 50(16):4615-4618. https://doi.org/10.1021/jf0203139

Silva BM, Andrade PB, Valentão P, Ferreres F, Seabra RM, Ferreira MA (2004). Quince (Cydonia oblonga Miller) fruit (pulp, peel, and seed) and jam: antioxidant activity. Journal of Agricultural and Food Chemistry 52(15):47054712. https://doi.org/10.1021/jf040057V

Silva BM, Andrade PB, Valentão P, Mendes GC, Seabra RM, Ferreira MA (2000). Phenolic profile in the evaluation of commercial quince jellies authenticity. Food Chemistry 71(2):281-285. https://doi.org/10.1016/S03088146(00)00134-5

Singal AG, Yopp A, Skinner CS, Packer M, Lee WM, Tiro JA (2012). Utilization of hepatocellular carcinoma surveillance among American patients: A systematic review. Journal of General Internal Medicine 27(7):861-867. https://link.springer.com/article/10.1007/s11606-011-1952-x

Singh R, Rastogi S, Dwivedi UN (2010). Phenylpropanoid metabolism in ripening fruits. Comprehensive Reviews in Food Science and Food Safety 9(4):398-416. https://doi.org/10.1111/j.1541-4337.2010.00116.x

Stojanović BT, Mitić SS, Stojanović GS, Mitić MN, Kostić DA, Paunović DĐ, Arsic BB, Pavlović, AN (2017). Phenolic profiles and metal ions analyses of pulp and peel of fruits and seeds of quince (Cydonia oblonga Mill.). Food Chemistry 232, 466-475. https://doi.org/10.1016/j.foodchem.2017.04.041

Sunil P (2016). Fresh-cut fruits and vegetables: technology, physiology and safety. Fresh-cut fruits and vegetables: technology, physiology and safety. CRC Press, Boca Raton: FL.

Wang SY, Lin HS (2000). Antioxidant activity in fruits and leaves of blackberry, raspberry, and strawberry varies with cultivar and developmental stage. Journal of Agricultural and Food Chemistry 48(2):140-146. https://doi.org/10.1021/jf9908345

Zampelas A, Micha R (2015). Antioxidants in health and disease. CRC Press (1st ed), Boca Raton, FL.
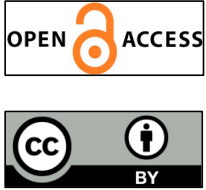

The journal offers free, immediate, and unrestricted access to peer-reviewed research and scholarly work. Users are allowed to read, download, copy, distribute, print, search, or link to the full texts of the articles, or use them for any other lawful purpose, without asking prior permission from the publisher or the author.

License - Articles published in Notulae Botanicae Horti Agrobotanici Cluj-Napoca are Open-Access, distributed under the terms and conditions of the Creative Commons Attribution (CC BY 4.0) License. (c) Articles by the authors; UASVM, Cluj-Napoca, Romania. The journal allows the author(s) to hold the copyright/to retain publishing rights without restriction. 